\title{
An Unusal Case of Epidermal Cyst in Submandibular Space
}

\author{
Rajesh Kar, Vandana Thorawade, Mohan Jagade, Anoop Attakkil, Shubhangi Kedar, \\ Dnyaneshwar Rohe, Kartik Parelkar, Rajanala Nataraj, Devkumar Rengaraja \\ Department of ENT \& Head \& Neck Surgery, Grant Government Medical College \& Sir J.J. Group of Hospitals, \\ Mumbai, India \\ Email: kar.rajeshkar@gmail.com
}

Received 5 June 2014; revised 4 July 2014; accepted 5 August 2014

Copyright (C) 2014 by authors and Scientific Research Publishing Inc.

This work is licensed under the Creative Commons Attribution International License (CC BY). http://creativecommons.org/licenses/by/4.0/

c) (i) Open Access

\begin{abstract}
Epidermal cysts are very common skin lesions and $1.6 \%$ are seen in oral cavity. But epidermal cyst in submandibular region is extremely rare with only 3 such reported cases in last 25 years. Here we present a rare case of epidermal cyst in left submandibular space in a 53-year-old female.
\end{abstract}

\section{Keywords}

\section{Epidermal Cyst, Submandibular Space, Epidermoid Cyst}

\section{Introduction}

Epidermal cyst usually occurs secondary to obstruction, lined by stratified squamous epithelium and filled with keratin. Epidermal cysts are very common skin lesions. Only 1.6\% of the cases are noted in oral cavity [1]. Oral cavity epidermoid cyst is known to cause external pressure over submandibular salivatory (Wharton's) duct producing symptoms of obstructive sialadenitis. However primary epidermal cyst of salivary glands appear to be very rare and literature search for last 25 years revealed only one such case in parotid gland [2] and three such cases in submandibular gland [3]-[5]. Epidermal cyst in submandibular region is likely to be mistaken for a salivary gland abscess, neoplasm, TB lymphadenitis, metastatic lymph node or any other cysts [4] [6] [7]. Excisional biopsy is needed for further confirmation.

\section{Case Report}

A 53-year-old female presented to our department with complaint of a swelling over her left side of neck since 7 months, which was insidious in onset and gradually progressive, pea nut size to start with which increased gra-

How to cite this paper: Kar, R., Thorawade, V., Jagade, M., Attakkil, A., Kedar, S., Rohe, D., Parelkar, K., Nataraj, R. and Rengaraja, D. (2014) An Unusal Case of Epidermal Cyst in Submandibular Space. International Journal of Otolaryngology and Head \& Neck Surgery, 3, 213-215. http://dx.doi.org/10.4236/ijohns.2014.35039 
dually to the present size of a lemon (Figure 1). Her main concern was cosmetic. Swelling was not associated with any fever/pain/difficulty in swallowing/difficulty in breathing/weight loss/discharge from swelling. There was no history of tuberculosis or any contact with any TB patient. There was no history of trauma to neck area.

On examination a swelling of $4 \times 4 \mathrm{~cm}$ was noted in left submandibular region which was, firm in consistency, ovoid in shape, mobile, nontender, nonpulsatile, skin above swelling was normal. No signs of inflammation were seen.

Ultrasonography of the local part suggested a $4 \times 3 \times 3 \mathrm{~cm}$ swelling probably a necrotic lymph node. 1st FNAC was inconclusive but repeat FNAC was suggestive of epidermal cyst. Patient underwent surgical excision of the lesion under general anaesthesia (Figure 2). Post operative histopathological examination confirmed the diagnosis of epidermal cyst (Figure 3).

\section{Discussion}

Cysts are more common skin lesion that consists of epithelial lined cavity, filled with viscous or semisolid epithelial degradation products [8]. Epidermal cyst usually occurs secondary to obstruction while dermoid cyst arises from developmental epithelial remnants or secondary to traumatic epithelial implantation of epithelial remnants [8]. Histologically epidermal cyst has stratified squamous epithelial lining and is usually filled with cheesy material or keratin. But dermoid or epidermoid cyst on other hand contains skin adnexa or other epidermal structure like sebaceous gland or hair follicle. Implantation dermoid is pathologically similar to epidermoid cyst but not derived from epidermal appendages and may contain foreign body [3].

Diagnosis of submandibular region swelling is difficult and ranges from sialeadenitis, sialolithiasis, abscess formation, TB lymphadenitis, metastasis of squamous cell carcinoma from oral cavity, mucocele, lymphoma, cystic hygroma, plunging ranula, branchial cyst, lipoma, epidermal and epidermoid cyst or other salivary gland cyst.

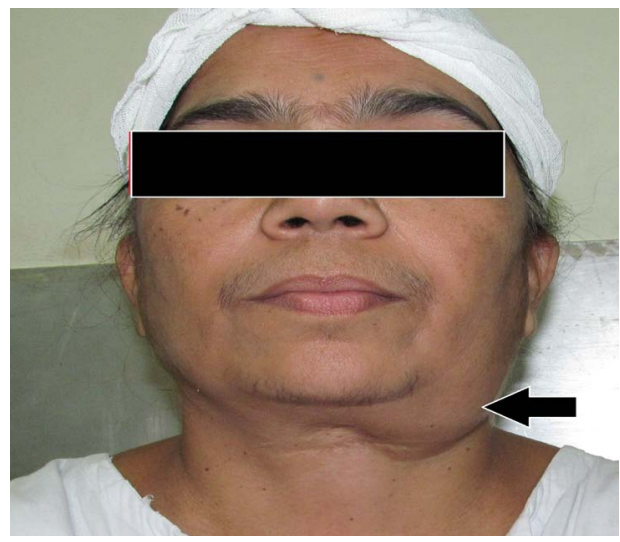

Figure 1. Showing swelling in left submandibular space.

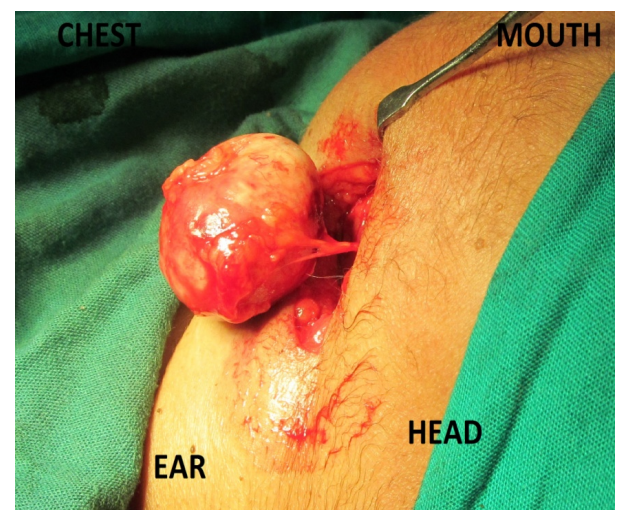

Figure 2. Showing excision of intact epidermal cyst from submandibular space. 


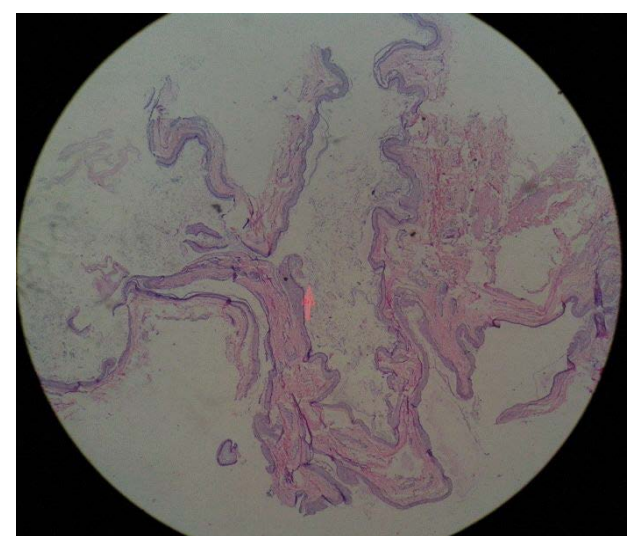

Figure 3. Showing histopathological section of epidermal cyst.

Postulated pathogenesis of epidermal cyst would be obstruction in salivary duct within the substance of the gland leading to epithelial lining cavity filled with viscous semisolid epithelial degradation products.

Patients usually present with cosmetic complaints. If the cyst stays for longer period of time it might get infected forming sinuses or fistulas. If allowed to gets huge it might give compression symptoms like difficulty in swallowing or respiration.

Surgical management includes complete excision of the cyst without any rupture because spillage of cystic content to underline fibro-vascular structure can cause post operative inflammation. Histopathological examination of cyst is required for confirmation of diagnosis. Care must be taken to avoid damage to surrounding structures like lingual nerve, mandibular branch of facial nerve and hypoglossal nerve [3]. Recurrence is very rare.

\section{Conclusion}

Epidermal cysts of head \& neck origin are quite rare entity with diagnostic challenge. Excision of the lesion is necessary to allow histopathological evaluation and to prevent complications due to growth of cyst such as imprigenement of adjacent structure and deformities of the head \& neck.

\section{References}

[1] Turetschek, K., Hospodka, H. and Steiner, E. (1995) Case Report: Epidermoid Cyst of the Floor of Mouth: Diagnostic Imaging by Sonography, Computed Tomography \& Magnetic Resonance Imaging. British Journal of Radiology, 68, 205-207. http://dx.doi.org/10.1259/0007-1285-68-806-205

[2] Rosai, J. (1996) Major \& Minor Salivary Glands. In: Moshby, R.J., Ed., Ackerman's Surgical Pathology, 8th Edition, Vol. 1, Mosby, St. Louis, 815-856.

[3] Prepageran, N., Rahmat, O. and Kuljit, S. (2005) Epidermal Cyst of Submandibular Gland. Medical Journal of Malaysia, 60, 483-484.

[4] Dutt, S.N., et al. (2000) Epidermoid Cyst of the Submandibular Gland. Indian Journal of Otolaryngology \& Head \& Neck Surgery, 52, 378-379.

[5] Janarthanam, J. and Mahadevan, S. (2012) Epidermoid Cyst of Submandibular Region. Journal of Oral and Maxillofacial Pathology, 16, 435-437. http://dx.doi.org/10.4103/0973-029X.102511

[6] Back, G.W., Fahmy, F. and Hosni, A. (2000) Submandibular Salivary Duct Cyst Mimicking an External Laryngocele. Journal of Laryngology \& Otology, 114, 305-307. http://dx.doi.org/10.1258/0022215001905427

[7] Truffin, J.R. and Theaker, E. (1991) True Lateral Dermoid Cyst of Neck. International Journal of Oral and Maxillofacial Surgery, 20, 275-276. http://dx.doi.org/10.1016/S0901-5027(05)80153-5

[8] Burkitt, H.G., Quick, C.R.G. and Gatt, D. (1990) Essential Surgery Problems, Diagnosis \& Management. Churchill Livingstone, Longmans, 581-582. 
Scientific Research Publishing (SCIRP) is one of the largest Open Access journal publishers. It is currently publishing more than 200 open access, online, peer-reviewed journals covering a wide range of academic disciplines. SCIRP serves the worldwide academic communities and contributes to the progress and application of science with its publication.

Other selected journals from SCIRP are listed as below. Submit your manuscript to us via either submit@scirp.org or Online Submission Portal.
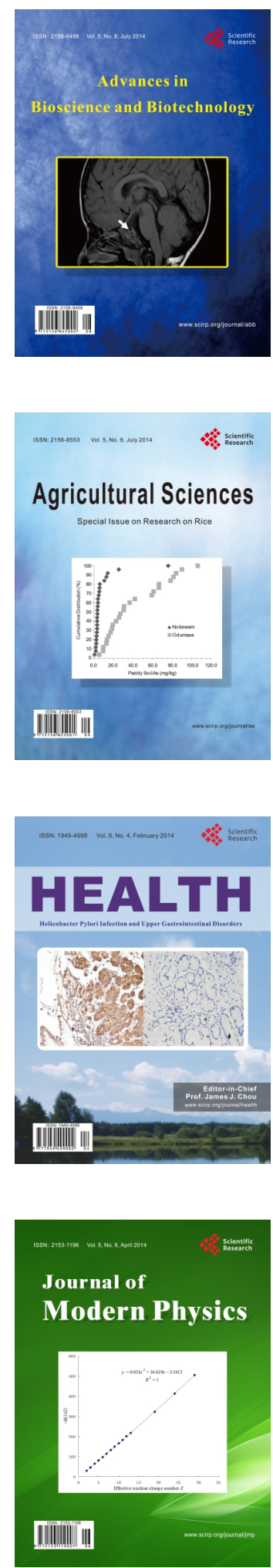
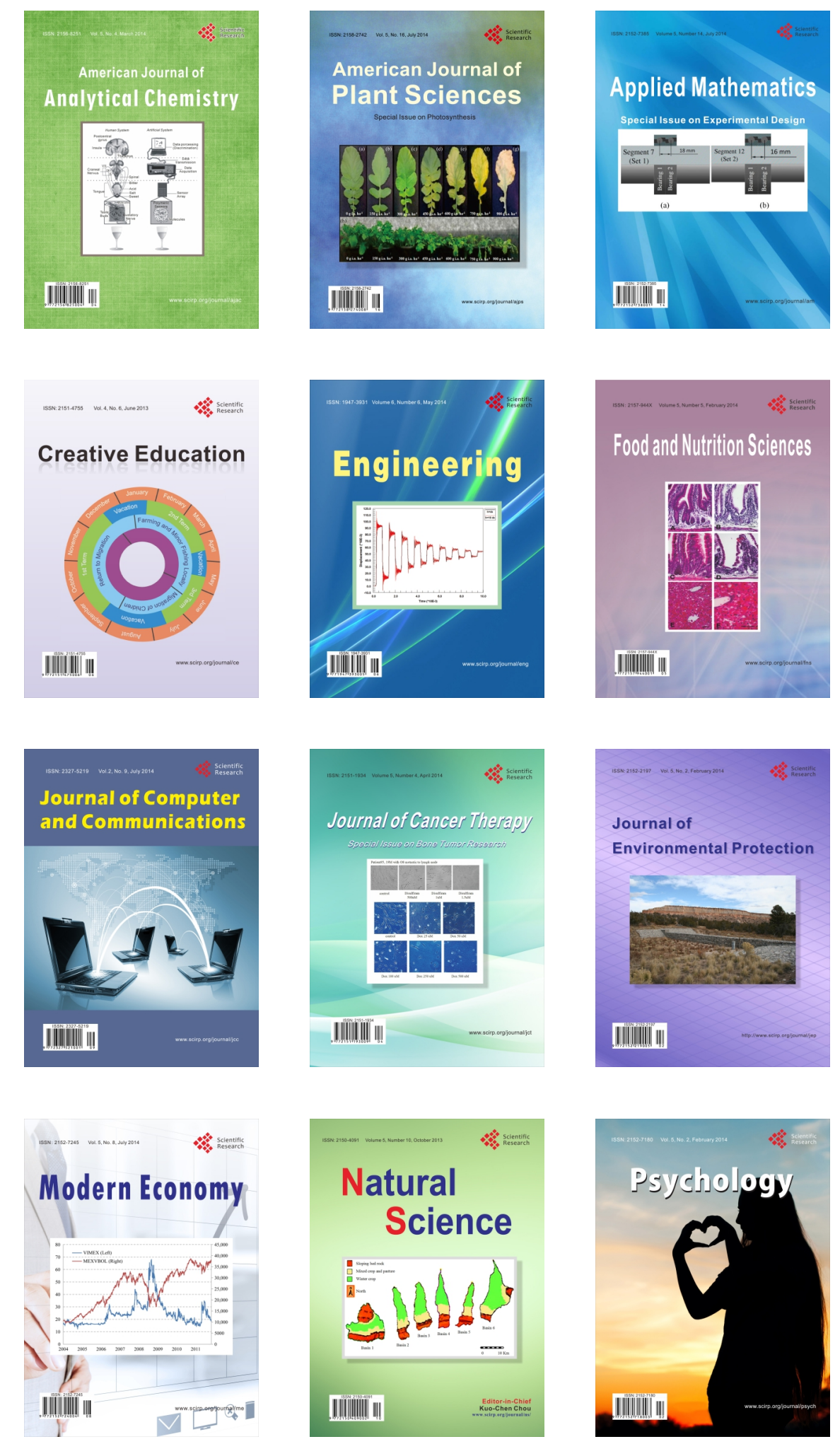